\title{
Studies on the phenology of some terrestrial orchids of Western Ghats, India
}

\author{
Soumya Mahabaleshwar Hegde ${ }^{1} \& \mathrm{~K}_{\text {Krishnaswamy }}{ }^{2 *}$ \\ ${ }^{1}$ Department of Botany, Kuvempu University, Shimoga 577 201, Karnataka, India \\ ${ }^{2}$ Department of Botany, Sahyadri Science College, Shimoga 577 201, Karnataka, India \\ *Email: krishna_swamy_k@yahoo.co.in
}

\section{ARTICLE HISTORY}

Received: 26 April 2021

Accepted: 08 June 2021

Available online: 01 July 2021

KEYWORDS

Phenology

Phenophase

Shimoga

Terrestrial orchids

Floristic studies

\section{ABSTRACT}

The present paper describes the distribution, natural habitat and phenology of some terrestrial orchids in Shimoga district, Karnataka. The phenophases viz., leafing, flowering, fruiting, fruit dehiscence are observed for 25 orchid taxa belonging to 13 genera in Shimoga district. They are Dienia ophrydis (J. Koenig) Seidenf., Disperis zeylanica Trimen., Epipogium roseum (D. Don) Lindl., Eulophia spectabilis (Dennst.) Suresh., Geodorum densiflorum (Lam.) Schltr., Habenaria crinifera Lindl., Habenaria elwesii Hook f., Habenaria furcifera Lindl., Habenaria grandifloriformis Blatt. \& Mc Cann., Habenaria heyneana Lindl., Habenaria longicorniculata J. Graham., Habenaria multicaudata Sedgw., Habenaria plantaginea Lindl., Liparis deflexa Hook. f., Liparis odorata (Willd) Lindl., Malaxis versicolor (Lindl.) Abeyw., Nervilia concolor (Blume) Schltr. Nervilia crociformis (Zoll. \& Moritzi) Seidenf., Nervilia infundibulifolia Blatt. \& Mc Cann., Nervilia plicata (Andrews) Schltr., Pecteilis gigantea (Sm.) Raf.. Peristylus plantagineus (Lindl.), Peristylus spiralis A. Rich., Satyrium nepalense D. Don, Zeuxine longilabris (Lindl.) Trimen. Phenology is the timing of plant life cycle events. Regular field visits were carried to observe the different life events. Most of the terrestrial orchids complete their life cycle in April to September or October month. The present research gives additional phenological aspects of terrestrial orchids in Shimoga district. Vegetative phenology is important to understand the ecology and instinct history of a plant species and may help to develop the conservation strategies of endangered species.

\section{Introduction}

The Orchidaceae is one of the largest families of flowering plants represented by $25000-35000$ species distributed in 600-800 genera in the world (1). In India, Orchidaceae is represented by about 152 genera and 1300 species (2), in which 84 species in 30 genera are endemic to Western Ghats (3). Family Orchidaceae in the state of Karnataka is represented by 203 species belonging to 59 genera, of which 17 species are terrestrial orchids in Shimoga district (4). The Biodiversity rich Western Ghats represents 300 species out of which 84 species under 30 genera are endemic and 15 species are endangered (5).

The orchid plants show the wide distribution in varied, climatic, edaphic, topographical situations and proved their successful adaptability. Orchids are attracting the plant explorers and taxonomic workers in Karnataka (6-9). Observations were also on 15 terrestrial orchids in Shimoga district (10).

Orchids are mainly categorized into two types terrestrial and epiphytic forms, terrestrial orchids grow on the ground while epiphytic ones grow on tree trunks or other substratum. Usually almost all orchids are associated with endophytic symbiotic fungus mainly in their roots. The terrestrial forms include those which inhabit the forest floor that is they grow under the shady environment. Terrestrial orchid are found to grow in various forest types such as scrub jungles, dry deciduous forests, moist deciduous forests, semi-evergreen as well as in evergreen forests. Orchids are distributed from sea level $1500 \mathrm{~m}$ altitudes with rainfall ranging from $60-300 \mathrm{~cm}$. The maximum numbers of terrestrial orchids are found in evergreen and semi-evergreen forests of the Western Ghats.

Plant phenology is the timing of major events in the life history of the plant with reference to seasons $(11,12)$. The phenology study deals not only the vegetative and reproductive phase corresponding to the climate and seasonal changes of a particular area but also determines the degree of reproductive synchrony with other plant species $(10,13)$. The phenology is a key tool for the plant management, conservation of species, floral biology, estimation of reproductivity and regeneration $(14,17)$. Flowering

(c) Hegde, Krishnaswamy (2021). This is an open-access article distributed under the terms of the Creative Commons Attribution License, which permits unrestricted use, distribution and reproduction in any medium, provided the original author and source are credited (https://creativecommons.org/licenses/by/4.0/). 
phenology is one of the most important characteristics in the life history of plants because it strongly determines fitness through sexual reproduction (10-13). The phenological studies mainly reflect the occurrence of plants in response to the environment, which include both vegetative and reproductive stages such as tuber formation, leaf flushing and shedding, bud formation, flowering, fruiting, dehiscence and seed germination. Phenological studies are mainly depending on the observation of life cycle events occurring at a given location over a time scale of several years. Both external and internal factors govern the plant phenology. Internal inherited factors are the cause of development of a species and it determines the phenological character even it grows in different climatic conditions. External factor alters the internal factors of the plants. External factors include temperature, rainfall, soil character, humidity, light intensity, altitude etc. Mainly three environment factors which trigger the phenological progress of the plant have been identified usually viz., photoperiod, temperature and moisture $(10,13,15)$. In the present study, detailed phenological studies including the vegetative and reproductive character of terrestrial orchid species were done from different talukas of Shimoga district, Karnataka. Phenological study helps to understand strategies of the species in a particular type of ecosystem. It is also important to understand the ecology and instinct history of a species which in turn help to develop the conservation strategies of rare, endemic and endangered species. Therefore, it is necessary to study the phenology of different taxa for the analysis of reproductive biological aspects.

\section{Materials and Methods}

The present work is mainly based on a taxonomic survey in the different forest types of Shimoga district those are evergreen, semi-evergreen, moist and dry deciduous forests and scrub forests in a district during the year January 2018 - January 2021. Collections were made from 7 talukas of Shimoga district. The coordinates of Shimoga district are at $13.9167^{\circ}$ North, $75.5667^{\circ}$ East and mean elevation of $640 \mathrm{~m}$ above sea level (NRDMS Centre Z. P Office Shimoga) (Fig. 1). Extensive field visits were conducted during different seasons of the year to collect flowering and fruiting stages. Field data regarding habit, habitat, phenology and other associated informations were recorded. Orchid species were collected from Shimoga district for the phenological observation viz., Dienia ophrydis (J. Koenig) Seidenf., Disperis zeylanica Trimen., Epipogium roseum (D. Don) Lindl., Eulophia spectabilis (Dennst.) Suresh., Geodorum densiflorum (Lam.) Schltr., Habenaria crinifera Lindl., H. elwesii Hook. f., $H$. grandifloriformis Blatt. \& Mc Cann., $H$. heyneana Lindl., $H$. longicorniculata J. Graham., $H$. furcifera Lindl., $H$. multicaudata Sedgw, $H$. plantaginiea Lindl., Liparis deflexa Hook. f., Liparis odorata (Willd.) Lindl., Malaxis versicolor (Lindl.) Abeyw., Nervilia concolor (Blume) Schltr. N. crociformis (Zoll. \& Moritzi) Seidenf., $N$. infundibulifolia Blatt. \& Mc Cann., N. plicata (Andrews) Schltr., Pecteilis gigantea (Sm.) Raf..

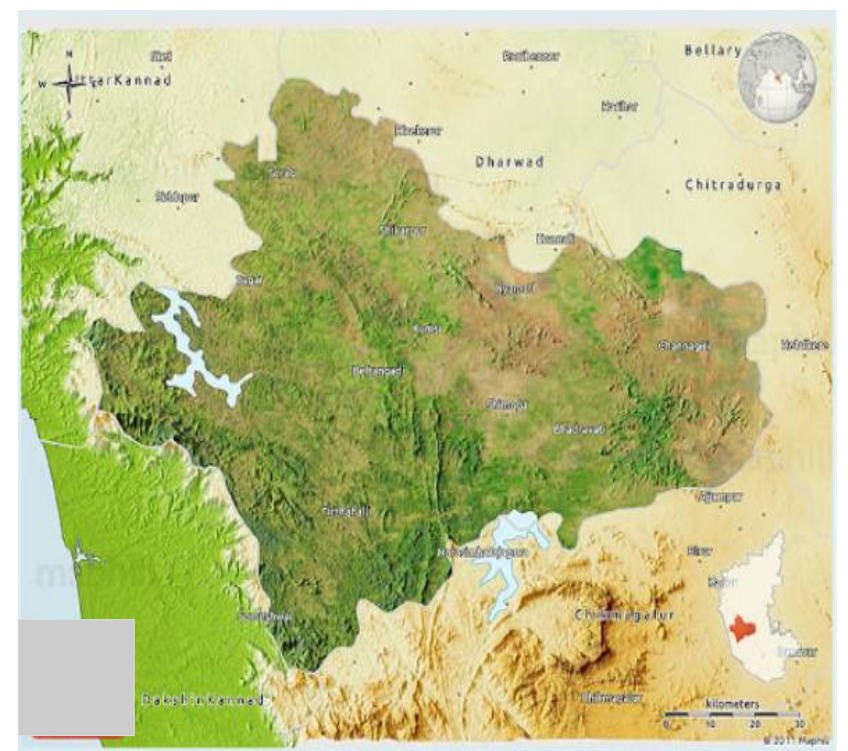

Fig. 1. Study area - Shimoga district in Karnataka state, India.

Peristylus plantagines (Lindl.), P. spiralis A. Rich., Satyrium nepalense D. Don, Zeuxine longilabris (Lindl.) Trimen. Specimens were identified with the help of regional floras and monographs on Orchidaceae $(4,10,18)$. Necessary photographs were also taken during field visits. The plants are collected from their natural habitats and maintained in the net house for further observation. Parameters are categorized into two parts vegetative and reproductive characters. Measurements were taken with the help of a scale or ruler. The numbers of flowers were counted from 5 plants and average values are recorded. Detailed studies of both categories were made from healthy plant species. Herbarium was prepared as described (20). The specimens are deposited in the herbarium, Department of Botany, Sahyadri Science College, Shimoga, Karnataka, India.

\section{Results and Discussion}

It is observed that rain plays a major role in the growth and development of most of the terrestrial orchid species. Terrestrial orchids start to produce leafy shoots at the onset of rainy season. Terrestrial forms absorb their nutrition directly from the soil through the roots. In terrestrial species mainly three kinds of roots are present, (1) one adapted to absorption and fixation. (2) Tuber adapted to nutritive substance storage. (3) One specialized in storage, absorption and fixation (16). Plant tubers have a capacity to survive in the dry season and nourish the plant till the emergence of necessary or favourable conditions and produce new shoots in the upcoming rainy season. Majority of the terrestrial orchids possess rhizome and some have tuber, size and shape of the rhizome vary from species to species. Rhizome has small nodes and internodes and stores plenty of reserve food material, which helps to withstand in dry condition. Malaxis versicolor (Fig. 2 A) shows runner type of modification with pseudobulbs and has nodes and internodes. In this plant young shoots produces at the nodal region. The emergence of new shoots in respect to time varies 
among the species. It is observed that the maximum number of species sprout out new shoots in the month of April to August. Species like Liparis deflexa,

L. odorata and Malaxis versicolor sprout their shoots

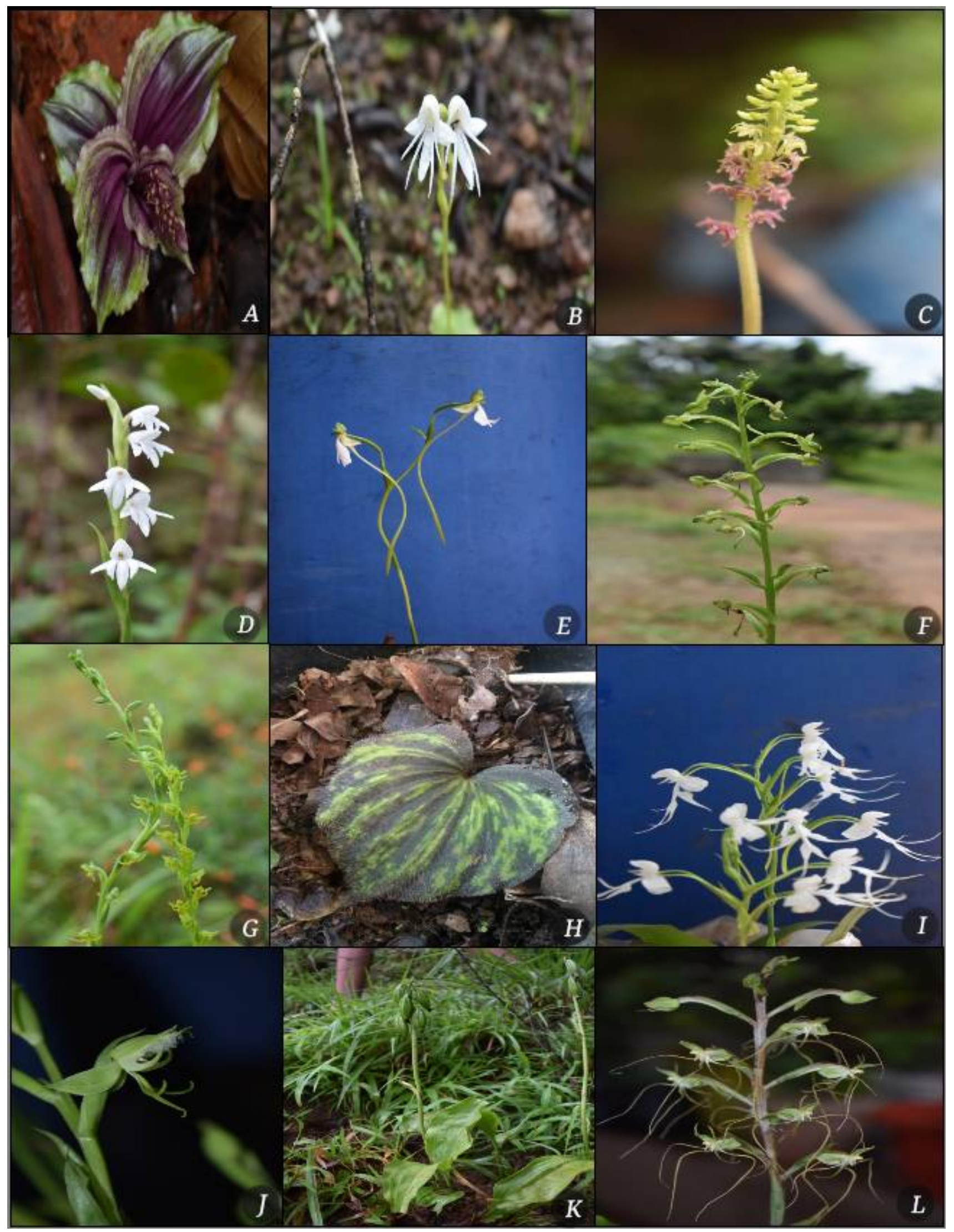

Fig. 2. A. Malaxis versicolor B. Habenaria grandifloriformis C. Dienia ophrydis D. Habenaria heyneana E. Habenaria longicorniculata F. Habenaria ovalifolia G. Peristylus spiralis $\mathbf{H}$. Nervilia plicata I. Habenaria crinifera J. Habenaria elwesii K. Geodorum densiflorum L. Habenaria multicaudata. 
in February - March. During the present study, it is found that a warm to high temperature with sufficient rainfall and moisture favour the sprout of new shoots in most of the species.

In terrestrial orchids, stems exhibit variations in their shape and size ranging from short slender to thick and fleshy, erect and covered with leaf sheaths. The height of the stem varies from species to species. Maximum stem height is observed in Pecteilis gigantea $(450 \mathrm{~mm})$ smallest in Habenaria grandifloriformis $(23 \mathrm{~mm})$, and Nervilia crociformis (40 mm). Leaves in terrestrial orchids conform to the monocotyledons pattern. In terrestrial forms, leaf is long and plicate or short cordate, elliptic, oblong, linear, ovate shape is also observed. Longest leaf is observed in Geodorum densiflorum (145 mm) (Fig. 2, $\mathrm{K})$ and shortest in Habenaria grandifloriformis (17 $\mathrm{mm}$ ). Highly thick short leaf is observed in Habenaria grandifloriformis (Fig. 2, B), (Table 1).

In terrestrial forms, the inflorescence is terminal only. Mainly inflorescence is produced from a leafy shoot but in few cases like Nervilia crociformis, $N$. plicata, N. concolor, flowers bloom first later on single leaf develops. The Inflorescence is in simple or compound racemes. In $N$. crociformis and $N$. infundibulifolia inflorescence are single-flowered. The length of the inflorescence varies from one species to another. A maximum length of the inflorescence is found in Pecteilis gigantea (350-470 mm). Whereas minimum in Nervilia crociformis $(25-30 \mathrm{~mm})$. The size of flowers varies among different species. The flower shows a variety of colours viz., white, yellow, pinkishwhite, purplish-white among the species studied (Table 2). Majority of the species initiate flowering buds during the month of June-July with the start of the rainfall. In the case of Nervilia spp. flowers develop from the month of March to April. The flower peak was recorded during the rainy season in the month of July to October.

The number of flower per inflorescence varies from species to species and is related to the length of the inflorescence. The number of flower in inflorescence varies from single to many. Single flower is observed in Nervilia crociformis and $N$. infundibulifolia (Table 2). Most of the inflorescence is raceme type; some are spike type. Maximum peduncle length recorded in Pecteilis gigantea during the study.

The different parts such as the sepals, petals and the labellum largely contribute to the beauty of a flower. The sepals and petals show variations from species to species with respect to shape, size and colour (Table 3 ). The petals are more pronounced in colour than the sepals and different in size. It is revealing that the greater the length and breadth ratio found in Pecteilis gigantea, and shorter as found in all Malaxis and Liparis spp. studied. The labellum is the most prominent of all perianth parts, with a different shade in colour, shape and size (Table 3 ). This is the most attractive parts of the flower of an orchid and well displayed by all the studied species. The length of labellum varies from one species to another and recorded maximum in Pecteilis gigantea, the minimum labellum length is observed in Malaxis versicolor (3 mm) (Fig. 2, A).
Terrestrial orchid species usually spend a major portion of the life cycle in the vegetative phase. The initiation of flower in the month of June marks the beginning of the reproductive phase of their life cycle. After full blooming in August - September, growth of the flower-bearing offshoot ceases and pod matures in August - October (Fig. 3). Some species like Nervilia plicata (Fig. 2, H) shed their seeds in April - May and Habenaria. grandifloriformis (Fig. 2, B) produce seeds in April - August (Table 4). The chief mode of propagation in most of the species is from the rhizome which develops during May - June. A strong seasonality exists with respect to vegetative and reproductive phenology in terrestrial forms.

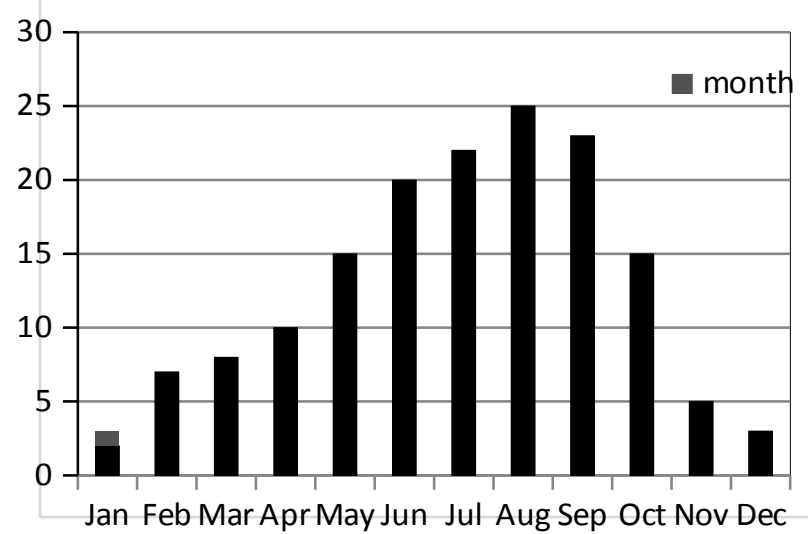

Fig. 3. Terrestrial orchid flowering and fruiting in different months.

Increase or decrease of the day length, temperature, pre-monsoon and post-monsoon, dry period all these are responsible for leaf formation and maturation. The highest flowering peak was recorded during monsoon in July - September, ripening of the majority of fruits in August - October month. The process of fruit formation, maturation, retention, dehiscence was found to be the longest phenophase in all the species. The difference in the phenological events among the species, majority of the species shows bursting of the seed pod during the month of August-October, dehiscence of seed pod occurs during the same or subsequent month of bursting in all the species, which provides a better chance of dispersal of seeds by a strong wind. Seeds are very minute, the colour of the seeds varies from white to brown. All the seed pod breaks in a single longitudinal slit at first and gradually two to three additional slits develop facilitating wind dispersal. Fruiting stage represented long term phenology records than leaf and flower phenology (19).

\section{Conclusion}

Phenology is the study of the timing of recurring biological events, among phases of the plant species, which provides background for collecting and synthesizing detailed quantitative information on the rhythms of plant communities. It is important to study the phenology of a plant so as to give a complete understanding of their morphology, structure and forms for various developments and its management in scientific study. The phenological 
Table 1. Terrestrial Orchid with vegetative characters.

\begin{tabular}{|c|c|c|c|c|c|c|c|}
\hline Sl. No. & Plant name & Type & Root & $\begin{array}{l}\begin{array}{l}\text { Height } \\
\text { of stem } \\
(\mathrm{mm})\end{array} \\
\end{array}$ & Leaf shape & $\begin{array}{l}\text { Length of } \\
\text { leaf }(\mathrm{mm})\end{array}$ & $\begin{array}{c}\text { Voucher } \\
\text { specimen } \\
\text { number }\end{array}$ \\
\hline 1. & Dienia ophrydis & Erect & Elongated & 120 & Lance shaped & 76 & KUSSCKS02 \\
\hline 2. & Disperis zeylanica & Erect & Oblong tuber & 130 & Heart shaped & 17 & KUSSCKS03 \\
\hline 3. & Epipogium roseum & Erect & Rhizome & 110 & Leafless & - & KUSSCKS05 \\
\hline 4. & Eulophia spectabilis & Erect & Rhizome & 130 & Pleated & 55 & KUSSCKS06 \\
\hline 5. & Geodorum densiflorum & Erect & Pseudo bulb & 158 & Pleated & 145 & KUSSCKS07 \\
\hline 6. & Habenaria crinifera & Erect & Oblong tuber & 250 & Oblong & 115 & KUSSCKS08 \\
\hline 7. & H. elwesii & Erect & Oblong tuber & 230 & Elliptic & 87 & KUSSCKS 11 \\
\hline 8. & H. grandifloriformis & Erect & Oval tuber & 23 & Heart-shaped & 19 & KUSSCKS13 \\
\hline 9. & H. heyneana & Erect & Ovoid tuber & 90 & Oblong & 67 & KUSSCKS14 \\
\hline 10. & H. multicaudata & Erect & Oblong tuber & 430 & Elliptic & 98 & KUSSCKS17 \\
\hline 11. & H. longicorniculata & Erect & Oval tuber & 325 & Oblong & 80 & KUSSCKS15 \\
\hline 12. & H. furcifera & Erect & Oval tuber & 290 & Elliptic & 78 & KUSSCKS12 \\
\hline 13. & H. plantaginea & Erect & Ellipsoid tuber & 140 & Elliptic & 65 & KUSSCKS18 \\
\hline 14. & Liparis deflexa & Erect & Round Tuber & 70 & Pleated & 58 & KUSSCKS20 \\
\hline 15 & L. odorata & Erect & Round Tuber & 80 & Pleated & 60 & KUSSCKS22 \\
\hline 16. & Malaxis versicolor & Erect & Ovoid pseudo bulb & 140 & Ovate shaped & 67 & KUSSCKS25 \\
\hline 17. & Nervilia concolor & Flattened & Round Tuber & 50 & Heart-shaped & 45 & KUSSCKS26 \\
\hline 18. & N. crociformis & Flattened & Round Tuber & 40 & Kidney shaped & 38 & KUSSCKS28 \\
\hline 19 & N. infundibulifolia & Flattened & Round Tuber & 40 & Heart-shaped & 40 & KUSSCKS27 \\
\hline 20. & N. plicata & Flattened & Round Tuber & 60 & Heart-shaped & 42 & KUSSCKS29 \\
\hline 21. & Pecteilis gigantea & Erect & Ellipsoid Tuber & 450 & Lance shaped & 140 & KUSSCKS31 \\
\hline 22. & Peristylus plantagineus & Erect & Ellipsoid Tuber & 260 & Pleated, elliptic & 80 & KUSSCKS34 \\
\hline 23. & P. spiralis & Erect & Oval Tuber & 230 & Elongated & 70 & KUSSCKS36 \\
\hline 24. & Satyrium nepalense & Erect & Oblong Tuber & 320 & Ovate & 85 & KUSSCKS37 \\
\hline 25. & Zeuxine longilabris & Erect & Rhizome & 240 & Ovate & 56 & KUSSCKS40 \\
\hline
\end{tabular}

Table 2. Details of the inflorescence of terrestrial orchids.

\begin{tabular}{|c|c|c|c|c|c|c|}
\hline Sl. No. & Plant name & Type & Position & Colour of flower & $\begin{array}{c}\begin{array}{c}\text { Length of } \\
\text { peduncle in } \\
\mathrm{mm}\end{array} \\
\end{array}$ & No. of flowers \\
\hline 1. & Dienia ophrydis & Spike & Terminal & Pink & $150-250$ & Many \\
\hline 2. & Disperis zeylanica & Cyme & Terminal & Pale pink & $70-100$ & $1-2$ \\
\hline 3. & Epipogium roseum & Raceme & Terminal & Pale pink & $150-400$ & $2-6$ \\
\hline 4. & Eulophia spectabilis & Unbranched raceme & Terminal & Pale green & $250-350$ & $6-15$ \\
\hline 5. & Geodorum densiflorum & Raceme & Terminal & Pink & $200-400$ & Many \\
\hline 6. & Habenaria crinifera & Terminal cyme & Terminal & White & $70-100$ & $5-10$ \\
\hline 7. & H. elwesii & Unbranched raceme & Terminal & White & $100-120$ & $5-15$ \\
\hline 8. & H. grandifloriformis & Terminal cyme & Terminal & White & $50-80$ & $2-3$ \\
\hline 9. & H. heyneana & Spike & Terminal & White & $100-120$ & $10-15$ \\
\hline 10. & H. multicaudata & Raceme & Terminal & Greenish-yellow & $150-450$ & Many \\
\hline 11. & H. longicorniculata & Unbranched raceme & Terminal & White & $100-150$ & $2-4$ \\
\hline 12. & H. furcifera & Raceme & Terminal & Green & $120-160$ & Many \\
\hline 13. & H. plantaginea & Raceme & Terminal & White & $70-180$ & Many \\
\hline 14. & Liparis deflexa & Spike & Terminal & Green & $50-150$ & Many \\
\hline 15 & L. odorata & Spike & Terminal & Brownish-yellow & $80-120$ & Many \\
\hline 16. & Malaxis versicolor & Spike & Terminal & Maroon & $150-250$ & Many \\
\hline 17. & Nervilia concolor & Cyme & Terminal & Green & $35-40$ & $2-5$ \\
\hline 18. & N. crociformis & Solitary cyme & Terminal & pale blue & $25-30$ & Single flower \\
\hline 19 & N. infundibulifolia & Solitary cyme & Terminal & Purple & $30-60$ & Single flower \\
\hline 20. & N. plicata & Cyme & Terminal & Purple & $100-150$ & $2-3$ \\
\hline 21. & Pecteilis gigantea & Raceme & Terminal & White & $350-470$ & $2-4$ \\
\hline 22. & Peristylus plantagineus & Unbranched spike & Terminal & White & $150-350$ & Many \\
\hline 23. & P. spiralis & Spike & Terminal & Green & $100-170$ & Many \\
\hline 24. & Satyrium nepalense & Unbranched spike & Terminal & Dense pink & $150-200$ & Many \\
\hline 25. & Zeuxine longilabris & Raceme & Terminal & White & $120-200$ & $4-15$ \\
\hline
\end{tabular}


Table 3. Floral phenophases of the terrestrial orchids.

\begin{tabular}{|c|c|c|c|c|c|c|c|c|c|c|c|c|c|}
\hline \multirow{3}{*}{$\begin{array}{l}\text { Sl. } \\
\text { No. }\end{array}$} & \multirow{3}{*}{ Plant name } & \multirow{3}{*}{$\begin{array}{c}\text { Size } \\
\text { in } \\
\text { mm }\end{array}$} & \multicolumn{11}{|c|}{ Flower } \\
\hline & & & \multicolumn{2}{|c|}{ Dorsal sepal } & \multicolumn{3}{|c|}{ Lateral sepal } & \multicolumn{3}{|c|}{ Petal } & \multicolumn{2}{|c|}{ Labellum } & \multirow[t]{2}{*}{ Pollinia } \\
\hline & & & shape & $\begin{array}{c}\mathrm{L} \\
\mathbf{m m}\end{array}$ & $\begin{array}{c}\text { B } \\
\mathbf{m m}\end{array}$ & $\begin{array}{c}\mathbf{L} \\
\mathbf{m m}\end{array}$ & $\begin{array}{c}\text { B } \\
\mathbf{m m}\end{array}$ & shape & $\begin{array}{c}\mathrm{L} \\
\mathbf{m m}\end{array}$ & $\begin{array}{c}\mathrm{B} \\
\mathbf{m m}\end{array}$ & $\underset{\mathbf{m m}}{\mathbf{L}}$ & $\underset{\mathbf{m m}}{\mathrm{B}}$ & \\
\hline 1. & Dienia ophrydis & $4-6$ & narrow & 3 & $1.3 \begin{array}{l}\text { Egg- } \\
\text { shaped }\end{array}$ & 3 & 1 & linear & 2 & 4 & 2.3 & 2 & 2 \\
\hline 2. & Disperis zeylanica & $6-9$ & linear & 8 & 5 obovate & 8 & 5 & obovate & 5 & 4 & 5 & 5 & 2 \\
\hline 3. & Epipogium roseum & $10-13$ & Lance shaped & 8 & 2 oblong & 8 & 2 & linear & $5-6$ & $6-8$ & 11 & 5 & 2 \\
\hline 4. & Eulophia spectabilis & $15-20$ & Oval & 3 & 4 oval & 5 & $6-7$ & linear & 6 & 7 & 15 & $5-7$ & 2 \\
\hline 5. & $\begin{array}{l}\text { Geodorum } \\
\text { densiflorum }\end{array}$ & $20-40$ & Obovat-oblong & 11 & 13 oval & 3 & 4 & oval & 5 & 7 & 11 & 10 & 2 \\
\hline 6. & Habenaria crinifera & $10-25$ & elliptic & $9.5-13$ & 5-7 spreading & $9-13$ & 6-7 & bilobed & $1-2$ & $1-2$ & $1.5-2$ & $1.1-1.5$ & 2 \\
\hline 7. & H. elwesii & $8-10$ & acuminate & $2.5-3.5$ & 2.5-3.7 spreading & $\begin{array}{r}3.5- \\
4.5 \\
\end{array}$ & $\begin{array}{l}2.4- \\
3.5 \\
\end{array}$ & fringed & $7-9$ & $5-6$ & $2-3$ & $1-2$ & 2 \\
\hline 8. & H. grandifloriformis & $11-16$ & $\begin{array}{l}\text { Obovate- } \\
\text { oblong }\end{array}$ & $3.9-4.3$ & 2.8-3.4 spreading & $\begin{array}{r}4.2- \\
5.6\end{array}$ & $\begin{array}{l}2.3- \\
3.8 \\
\end{array}$ & obovate & $\begin{array}{r}12- \\
14 \\
\end{array}$ & $7-8$ & $6-8$ & $1.5-2.5$ & 2 \\
\hline 9. & H. heyneana & $13-27$ & Obtuse & 3.8 & 5 spreading & 4-7 & $3-8$ & bilobed & 5 & 3 & 5 & 2.5 & 2 \\
\hline 10. & H. multicaudata & $10-15$ & acute & 5 & 1.2 bilobed & $4-5$ & 1.5 & lobed & 1.5 & 1.5 & 2 & 2 & 2 \\
\hline 11. & H. longicorniculata & $10-20$ & acuminate & $3.5-4.5$ & ovate & 4 & 6 & subfalcate & 3 & 7 & 11 & 5 & 2 \\
\hline 12. & H. furcifera & $5-10$ & oval & 2 & 3 oval & 3.5 & 2.5 & oval & 3-4 & $2-3$ & 5 & $5-6$ & 2 \\
\hline 13. & H. plantaginea & $15-16$ & obovate & 13 & 10 oblong & 11 & 4 & obovate & 9.8 & 3.4 & 11.5 & 5.6 & 2 \\
\hline 14. & Liparis deflexa & $10-12$ & oval & 5 & 2.5 oblong & 5 & 3.5 & Lobed & 5 & 5 & 5.6 & 4.5 & 2 \\
\hline 15 & L. odorata & $3-5$ & oval & 4 & 3.5 oblong & 4 & 3.5 & oval & 4 & 3 & 3.5 & 3 & 2 \\
\hline 16. & Malaxis versicolor & $5-8$ & linear & 4.2 & 3 lanceolate & 4.5 & 3.9 & lobed & 3.7 & 2.1 & 3 & 2.1 & 4 \\
\hline 17. & Nervilia concolor & $35-40$ & elongated & 17 & $\begin{array}{l}2 \begin{array}{l}\text { Lance } \\
\text { shaped }\end{array} \\
\text { shat }\end{array}$ & 15 & 3 & linear & 12 & 3 & 6 & 5 & 2 \\
\hline 18. & N. crociformis & $25-30$ & Lance shaped & 16 & 2 linear & 12 & 4 & fringed & 11 & 4 & 8 & 5 & 2 \\
\hline 19 & $N$. infundibulifolia & $20-30$ & Lance shaped & 15 & 4 linear & 13 & 4 & lobed & 10 & 4 & 15 & 5 & 2 \\
\hline 20. & N. plicata & $15-25$ & Lance shaped & 15 & 3 linear & 13 & 5 & $\begin{array}{l}\text { Lance } \\
\text { shaped }\end{array}$ & 9 & 3 & 10 & 4 & 2 \\
\hline 21. & Pecteilis gigantea & $50-60$ & linear & 34 & 18 triangular & 28 & 15 & oval & 14 & 6 & 7 & 4 & 2 \\
\hline 22. & $\begin{array}{l}\text { Peristylus } \\
\text { plantagineus }\end{array}$ & $20-30$ & oblong & 5.5 & oval & 10 & $4-5$ & Ovate & 3. & 2.5 & 3.5 & 2 & 2 \\
\hline 23. & P. spiralis & $15-20$ & ovate & 6.5 & 4.5 oblong & 10.5 & 3.5 & ovate & 3.5 & 2.5 & 5.5 & 3.5 & 2 \\
\hline 24. & Satyrium nepalense & $2-10$ & oblong & 5 & 2 oblong & 5 & 2 & oval & 4.2 & 2.2 & 2.5 & 3.5 & 2 \\
\hline 25. & Zeuxine longilabris & $1-3 \mathrm{~cm}$ & ovate & 7 & 2 ovate & 4 & 6 & ovate & 7 & 8 & 2 & 2.5 & 2 \\
\hline
\end{tabular}

Table 4. Details of fruits of terrestrial orchids.

\begin{tabular}{lllll}
\hline S1. No. & Plant name & Fruit type & Shape & Fruiting time \\
\hline 1. & Dienia ophrydis & Capsule & Oval & August-October \\
\hline 2. & Disperis zeylanica & Capsule & Pear shaped & June-September \\
\hline 3. & Epipogium roseum & Capsule & Pear shaped & April-May \\
\hline 4. & Eulophia spectabilis & Capsule & Ellipsoid & June-august \\
\hline 5. & Geodorum densiflorum & Capsule & Fusiform & July-September \\
\hline 6. & Habenaria crinifera & Capsule & Oval & June-September \\
\hline 7. & H. elwesii & Capsule & Pear shaped & June-September \\
\hline 8. & H. grandifloriformis & Capsule & Oblong & April-august \\
\hline 9. & H. heyneana & Capsule & Oblong & June-September \\
\hline 10. & H. multicaudata & Capsule & Oblong & June-September \\
\hline 11. & H. longicorniculata & Capsule & Pear shaped & July-September \\
\hline 12. & H. furcifera & Capsule & Pear shaped & August-October \\
\hline 13. & H. plantaginea & Capsule & Ellipsoid & May-September \\
\hline 14. & Liparis deflexa & Capsule & Pear shaped & June-September \\
\hline 15 & L. odorata & Capsule & Pear shaped & June-September \\
\hline 16. & Malaxis versicolor & Capsule & Ellipsoid & June-September \\
\hline 17. & Nervilia concolor & Capsule & Ellipsoid & May-June \\
\hline 18. & N. crociformis & Capsule & Ellipsoid & March-May \\
\hline 19 & N. infundibulifolia & Capsule & Fusiform & March-May \\
\hline 20. & N. plicata & Capsule & fusiform & March-May \\
\hline 21. & Pecteilis gigantea & Capsule & Ellipsoid & June-September \\
\hline 22. & Peristylus plantagineus & Capsule & Oblong & July-October \\
\hline 23. & P. spiralis & Capsule & Fusiform & July-October \\
\hline 24. & Satyrium nepalense & Capsule & Spindle-shaped & August-December \\
\hline 25. & Zeuxine longilabris & Capsule & Oval & February-March \\
\hline & & &
\end{tabular}

studies are important for a better understanding of their biology, adaptations to environment, proper utilization of the available resources in management. Knowledge of the phenological character and how these are influenced by environmental factor is important for the prediction of potential effects of climate change on vegetation. The environmental factors play a major role in the phenology of 
terrestrial orchids in Shimoga district (10). Understanding of phenological process is valuable in understanding the plant function and structure and in providing the basis for developing management options. The phenological data obtained in the present study are useful in resource management and conservation of the individual species and also for the orchid growers for the floriculture industry. Plant phenology is a scientific study that provides the most basic information on a species for multiplication, propagation and also for the germplasm conservation and improvement.

\section{Acknowledgements}

Authors receives no external funding for this research. I would like to thank Dr Krishnaswamy. K research guide for his encouragement and support given during the study. The authors wish to thank the authorities of Karnataka Forest Department for giving permission to collect the specimens from the study area. I am also grateful to my colleagues for their cooperation to complete my research work.

\section{Authors' contributions}

SMH carried out the field work, data collection, identification, photography, herbarium preparation, manuscript writing. KK carried out the field work, guided for data interpretation and manuscript writing. All authors have read and approved the manuscript.

\section{Conflict of interests}

Authors do not have any conflict of interests to declare.

\section{Ethical issues}

Authors do not have any ethical issues to declare.

\section{References}

1. Arditti J. Flower introduction in orchids. Orch Rev. 1966;74:208-17.

2. Roy SC, Sharma AK, Cytological Studies of Indian Orchids. Proc Indian Natl Sci Academy. 1972; 38(5):107-12.

3. Joshi M, Charles B, Ravikanth G, Aravind NA. Assigning conservation value and identifying hotspots of endemic diversity in the Western Ghats, India. Plant Diversity. 2017;39:263-72. https://doi.org/10.1016/j.pld.2017.08.002

4. Krishnaswamy K, Krishna kumar HN., Ramakrishna TM, Ramaswamy SN. Studies on distribution and phenology of orchids in Karnataka. Orchid Society of India, 2004;18(1-2):8196.

5. Satish kumar C. Endemic orchids of Western Ghats. In: Proc. Seminar On Eco development of Western Ghats. 1986;51-54.
6. Wight R. Icones Plantarum Indiae Orientalis:or figures of Indian Plants. 6 Vols. Madras (Wheldon \& Wesley Ltd. Hafner Publishing Co. New york). Cramer, Weinheim. Rep. ed. 1853. https://doi.org/10.5962/bhl.title.92

7. Cooke T. Flora of the Presidency of Bombay. 3 vols. Rep. ed. 1958. Botanical Survey of India, Calcutta, India. 1901-1908.

8. Gamble JS. Flora of the Presidency of Madras II parts. London (parts $8-11$ by C. E. C. Fischer) Botanical Survey of India. $2^{\text {nd }}$ rep. ed. In 3 vols. 1967.

9. Hooker JD. Flora of British India. Assisted by various botanists. Vols. 1-7. L. Reeve \& Co. Ltd. Ashford, Kent. 1872-97.

10. Prashant Kumar HG. A Study on Biology of some orchids. Ph.D. Thesis, Kuvempu University, Shimoga, Karnataka, India. 2016.

11. Desai PB, Patel NK. Phenological study of trees species of Satara range forest (North Gujarat), Life Science Leaflets. 2010;3:41-46.

12. Patil DA. Phenological study in papilionoid taxa in Dhule and Nandurbar district of Maharashtra (India). J New Biol Rep. 2019;8(2):148-54

13. Rathcke B, Lacey EP. Phenological patterns of terrestrial plants. Annu Rev Ecol Syst. 1985;16:179-21. https://doi.org/10.1146/annurev.es.16.110185.001143

14. Mulik NG, Bhosale, LJ. Flowering phenology of the mangroves from the West Cost of Maharashtra. J Bom Nat Hist Soc. 1989;86(3):355-39.

15. Borchert R. Phenology and control of flowering in tropical trees. $\quad$ Biotropica. https://doi.org/10.2307/2387949

16. Black PM. Orquideas. (Ed.). Ao Livro Tecnico S/A. Rio de Janeiro. 1973.

17. Adriana RM, Demetria Martha MC, Raul RG. Vascular epiphytes: The ugly duckling of phenological studies. Acta Biologica Colombiana. 2021;26(2):247-61. https://doi.org/10.15446/abc.v26n2.83473

18. Ramaswamy SN, Radhakrishna Rao, Arekal GD. Flora of Shimoga district, Prasaranga, University of Mysore, Mysore. 2001.

19. Tara K Miller, Amanda S Gallinat, Linnea C Smith, Richard B Primack. Comparing fruiting phenology across two historical datasets: Thoreau's observations and herbarium specimens. Annals of Botany. 2021; mcab019. https://doi.org/10.1093/aob/ mcab019

20. Rao RR, Sharma BD. A manual for Herbarium Collection Botanical Survey of India, Calcutta, 1990. pp 20.

Additional information

Peer review information: Plant Science Today thanks Sectional Editor and the other anonymous reviewers for their contribution to the peer review of this work.

Reprints and permissions information is available at

https://horizonepublishing.com/journals/index.php/PST/open_access_policy

Publisher's Note: Horizon e-Publishing Group remains neutral with regard to jurisdictional claims in published maps and institutional affiliations.

To cite this article: Hegde S M, Krishnaswamy K. Studies on the phenology of some terrestrial orchids of Western Ghats, India. Plant Science Today. 2021;8(3):662-668. https://doi.org/10.14719/pst.2021.8.3.1233

Plant Science Today, published by Horizon e-Publishing Group, is covered by Scopus, Web of Science, BIOSIS Previews, Clarivate Analytics, etc. See https://horizonepublishing.com/journals/index.php/PST/indexing_abstracting 